\title{
BAITUL MAAL WAT TAMWIL DIPANDANG DARI SUDUT AGAMA, SERTA SEJARAH BERDIRINYA DI INDONESIA
}

\author{
Tuty Sariwulan*
}

\begin{abstract}
Islamic banking hasn't been able to touch the micro and small enterprises (MSEs) from street vendors to merchants in the traditional market which is usually referred as the grassroots economy.

Driven by a sense of deep concern to many poor people are trapped by moneylenders and also in order to provide an alternative for those to expand its business but can't be directly to related Islamic banking ( BMI and BPRS) because the business it's relatively small and micro, then in 1992 a small financial institutions that operate and use a combination of concepts Baitul Maal and Baitul Tamwil as the target and the scale on the micro business sector. The institutions "ventured" named Baitul Maal Wat Tamwil abbreviated BMT.
\end{abstract}

\section{PENDAHULUAN}

Baitul Maal Wattamwil, yang selanjutnya disingkat BMT atau disebut juga dengan nama lain yaitu : Balai Usaha Mandiri Terpadu.

Menurut Heri sudarsono dalam bukunya "Bank dan Lembaga keuangan syariah" mendefinisikan BMT ke dalam 2 fungsi utama :

a. Bait al maal : lembaga yang mengarah pada usaha-usaha pengumpulan dan penyaluran dana yang non profit, sepertihalnya zakat, infaq, dan sadaqoh.

b. Bait at-tamwil : lembaga yang mengarah pada usaha pengumpulan dan penyaluran dana komersial.

Sudarsono menyimpulkan bahwa BMT mempunyai dua fungsi, yaitu : fungsi non profit sebagai

* Tuti Sariwulan. Dosen Fakultas Ekonomi Universitas Negeri Jakarta landasan historis bahwa baitul maal pada masa Islam klasik adalah berfungsi sebagai dana umat dan penyeimbang perekonomian, dan fungsi kedua yaitu fungsi profit karena sebagai perpanjangan tangan dari bank Syariah

Kegiatan BMT adalah mengembangkan usaha yang produktif dalam meningkatkan kualitas ekonomi terutama pengusaha kecil yang berada di pinggiran kota/diluar kota atau di pedesaan. Sistem yang digunakan BMT adalah "sistem Syari'ah".

BMT Berorientasi bisnis, mencari keuntungan bersama, namun tetap berdasarkan "Syariah Islam" dalam meningkatkan ekonomi menengah kebawah, dan juga diperuntukkan masyarakat lingkungan sekitarnya, dengan kata lain BMT merupakan usaha milik bersama untuk 
masyarakat kecil. BMT dapat pula didirikan dalam Koperasi..

BMT memiliki manajemen yang rapi, tertata administrasi dan pembukuannya memakai program komputer yang dikerjakan oleh pegawai yang profesional berpendidikan minimal S1.

BMT bukan lembaga sosial, namun bergerak juga di bidang sosial seperti : menerima dan atau menyalurkan Zakat, Infaq dan shodaqah. dan juga mengadakan pengajian rutin dan pembinaan secara berkala yang waktu dan tempatnya ditentukan.

BMT layak berdiri bila memenuhi kriteria : (1) Ada praktek rentenir atau lintah darat.(2) Ada potensi usaha kecil yang dapat dikembangkan (3) Adanya modal pendiri (Kecukupan modal) (4) Ada sejumlah toko yang merasa memiliki dan bertanggung jawab (5) .Ada komitmen pemberdayaan ekonomi ummat. (6) Ada modal awal terkumpul Rp 10 sampai 20 juta rupiah. (7) Apabila BMT sudah memiliki modal di atas Rp 500.000.000,- maka BMT boleh beralih menjadi BPR Syari'ah. (Prof Dr Ir M. Amin Aziz, Tata Cara Mendirikan BMT)

Secara ringkas tujuan dan dampak positif BMT antara lain (1) Menyalurkan dana untuk usaha bisnis kecil dan menengah dengan mudah dan bersih, karena didasarkan pada kemudahan dan bebas riba/ bunga. (2) Memperbaiki/ meningkatkan taraf hidup masyarakat bawah. Lembaga keuangan alternatif yang mudah diakses oleh masyarakat bawah dan menengah.

\section{Sejarah BMT Dipandang Dari Sudut Agama}

Keberadaan ekonomi Syariah sudah cukup lama dirindukan oleh umat Islam. Selama ini kegiatan ekonomi mengalami dualisme pandangan dalam konteks perekonomian antara Ekonomi dan Syariah. Dualisme ini muncul sebagai akibat dari ketidakmampuan umat untuk menggabungkan dua disiplin ilmu ekonomi dan syariah Islam, yang seharusnya saling mengisi dan menyempurnakan. Disatu pihak para ekonom, bankir, dan businessman yang aktif dalam menggerakkan roda pembangunan ekonomi, tetapi "lupa" membawa pelita agama karena memang tidak menguasai syariah terlebih lagi fiqih muamalah secara mendalam. Dilain pihak ditemukan para kyai dan ulama yang menguasai secara mendalam konsep-konsep fiqih, ushulul fiqh, ulumul Qur'an dan disiplin lainnya tetapi mereka kurang menguasai dan memantau tentang fenomena ekonomi dan gejolak business yang terjadi disekelilingnya. Akibatnya ada semacam tendensi: "biarlah kami mengatur urusan akhirat dan mereka untuk urusan dunia, padahal Islam adalah risalah untuk dunia dan akhirat (Antonio Syafi'i, 2000).

Akibat langsung dari hal tersebut diatas Islam senantiasa menjadi penonton dalam segenap peraturan ekonomi dan bisnis yang terjadi. Hal ini terjadi karena tidak ada yang menterjemahkan Al-Qur'an ke dalam usaha dan institusi bisnis yang nyata. Setiap kali hendak diadakan diskusi tentang ekonomi dan bisnis 
dalam perspektif Islam, dialog senantiasa macet karena "sang Ekonom" tidak mampu melihat alternatif lain dari sistem yang ada, manakala "sang Kyai" tidak mampu menyodorkan konsepnya untuk diterapkan dalam bentuk yang hidup dan nyata (Antonio Syafi'i, 2000).

\begin{tabular}{llr}
\multicolumn{1}{c}{ Apabila } & diteliti lebih lanjut, \\
sebenarnya & Islam & sangat \\
memperhatikan & bagaimana & harta
\end{tabular} (hasil kegiatan ekonomi) itu diperoleh dan untuk apa harta itu digunakan. Oleh karenanya Islam melarang mendapatkan harta dengan cara yang haram seperti : menipu, berbuat curang, mencuri, ber judi, mengurangi timbangan, menjualan barang haram, dan tak kalah gencarnya yang diperangi oleh Islam adalah masalah riba. Islam dengan tegas mengatakan bahwa haram hukumnya memakan riba. Larangan riba terdapat dalam AlQur'an, yang diturunkan tidak sekaligus melainkan secara bertahap, antara lain terdapat pada :

1. Surat Al-Baqarah ayat 275 yang artinya : Orang-orang yang makan (mengambil) riba tidak dapat berdiri melainkan seperti berdirinya orang yang kemasukan syaitan lantaran (tekanan) penyakit gila. Keadaan mereka yang demikian itu adalah disebabkan mereka berkata (berpendapat), sesungguhnya jual-beli itu sama dengan riba, padahal Allah telah menghalalkan jual-beli dan mengharamkan riba........"

2. Surat Al-Baqarah ayat 278-279 yang artinya : Hai orang-orang yang beriman bertaqwalah kepada Allah dan tinggalkan sisa riba (yang belum dipungut) jika kamu orang-orang yang beriman. Maka jika kamu tidak mengerjakannya (meninggalkan sisa riba) maka ketahuilah, bahwa Allah dan Rasul-Nya akan memerangimu. Dan jika kamu bertaubat (dari pengambilan riba), maka bagimu pokok hartamu, kamu tidak menganiaya dan tidak pula dianiaya.

3. Larangan Surat Ali Imran ayat 130, yang artinya : " Hai orangoorang yang beriman janganlah kamu memakan riba dengan berlipat ganda dan bertaqwalah kamu kepada Allah supaya kamu mendapat keberuntungan".

4. Surat An-Nisaa ayat 161 yang artinya : " Dan disebabkan mereka memakan riba, padahal sesungguhnya mereka telah dilarang dari padanya, dan karena mereka memakan harta orang dengan cara yang batil. Kami telah menyediakan untuk orang-orang yang kafir diantara mereka itu siksa yang pedih".

Riba dari segi istilah bahasa sama dengan "Ziyadah" artinya tambahan. Sedangkan menurut istilah tehnis, riba berarti pengambilan tambahan dari harta pokok (modal) secara bathil. Secara umum riba adalah penambahan terhadap hutang. Artinya : setiap penambahan pada hutang baik kualitas ataupun kuantitas, baik banyak maupun sedikit adalah riba dan diharamkan. 
Islam dapat memberi solusi agar memperoleh ketenangan dan keselamatan didunia serta keselamatan di akhirat. .Misalnya larangan terhadap riba, alternatif yang diberikan Islam dalam rangka rrienghapus riba dalam praktek mu'amalah yang dilakukan manusia melalui dua jalan. Jalan yang pertama, berbentuk shadaqah ataupun qardhul hasan yang rnerupakan solusi bagi siapa saja yang melakukan aktivitas riba untuk keperluan biaya hidup (konsumtif). Sedangkan jalan yang kedua adalah melalui sistem perbankan Islam yang didalamnya menyangkut perighimpunan dana melalui tabungan mudharubah, deposito musyawarah dan giro wadiah yang kemudian disalurkan melalui pinjaman dengan prinsip tiga hasil (seperti mudharabah, musyarakah), prinsip jual beli (bai ' bithaman ajil, mudarabah dan sebagainya) serta prinsip sewa/fee (Ijarah, bai'at takjiri dan lain-lain). Dari kedua jalan di atas, secara sistematik diatur dan dikelola melalui kelembagaan yang dalam istilah Islam disebut Baitul Maal wat Tamwil.'

Dalam sejarah perekonomian umat muslim, ada salah satu instansi yang telah memperhatikan aspek kebajikan pada kehidupan masyarakat, yaitu baitul maal yang memberikan kontribusi yang sangat signifikan dalam menyeimbangkan perekonomian umat Islam pada masa itu dengan memberikan dana subsidi kepada umat Islam yang membutuhkan yang dalam Islam disebut sebagai mustahik. Adapun sumber dana dari baitul maal yaitu dana zakat, infak, dan beberapa kebijakan yang telah ditentukan oleh khalifah (pemimpin) umat Islam pada waktu itu.

\section{Sejarah Berdirinya BMT Di Indosesia}

Latar belakang berdirinya BMT di Indonesia diawali dari kemampuan Perbankan sangat terbatas untuk menjangkau sektor usaha mikro dan kecil sehingga dibutuhkan lembaga keuangan yang komersial seperti bank yang mampu dan dapat menjangkau sektor usaha kecil dan menengah (UMK). Lembaga keuangan formal ini belum menyentuh UMK misalnya pedagang yang ada di pasar tradisional, pedagang kaki lima sampai pedagang asongan yang biasanya disebut sebagai ekonomi rakyat kecil. Apabila diperhatikan secara seksama justru prosentase UMK jauh lebih besar dari usaha-usaha menengah keatas, sehingga akan terjadi ketimpangan pasar dalam bidang ekonomi.

Beberapa orang ada yang memperhatikan dan tersentuh dalam usaha mikro ini, kelompok individu yang memperhatikan UMK tersebut memberikan permodalan yang sangat dibutuhkan oleh UMK tersebut, individu tersebut sering dikenal di masyarakat umum sebagai rentenir. Keberadaan rentenir itu sendiri tidak membawa kemaslahatan bagi masyarakat banyak, karena justru ada beberapa permasalahan yang signifikan dalam bentuk kegiatan individu tersebut, diantaranya adalah 
bentuk permodalan yang dilakukan dari rentenir tersebut. Para rentinir biasanya meminjamkan uang mereka kepada para peminjam dengan beberapa ketentuan yang mengikat diantaranya penentuan bunga yang tinggi dengan jangka waktu pengembalian yang sangat pendek. Sehingga praktek ini secara tidak langsung tidak memberikan solusi akan permasalahan ekonomi rakyat kecil, akan tetapi menambah masalah perekonomian mereka yang sudah kompleks. Oleh Karena itu dibutuhkan instansi keuangan mikro baru yang mempunyai kompetensi baik dalam profesionalitas dan material yang bisa mengcover kebutuhan masyarakat akan hal itu, dan tidak menjerat mereka dalam lingkaran hutang yang berkepanjangan.

BMT ini dapat diharapkan menjadi penyokong UMK dan menggantikan praktek rentenir yang dianggap mencekik UMK dalam jeratan hutang yang berkepanjangan itu dan dapat menyeimbangkan pasaran Indonesia secara umum

BMT pada umumnya memiliki dua latar belakang pendirian dan kegiatan yang hampir sama kuatnya, yakni sebagai lembaga keuangan mikro dan sebagai lembaga keuangan syariah. Identifikasi yang demikian sudah tampak pada beberapa BMT perintis, yang beroperasi pada akhir tahun 1980-an sampai dengan pertengahan tahun 1990-an. Mereka memang belum diketahui secara luas oleh masyarakat, serta masih melayani kelompok masyarakat yang relatif homogen dengan cakupan geografis yang amat terbatas. Perkembangan pesat dimulai sejak tahun 1995, dan beroleh "momentum" tambahan akibat krisis ekonomi 1997/1998.

BMT secara umum telah terbukti berhasil menjadi lembaga keuangan mikro yang andal. Kemampuannya untuk menghimpun dana masyarakat terbilang luar biasa, mengingat mayoritas anggota dan nasabahnya adalah pelaku usaha berskala mikro, yang selama ini tidak diperhitungkan oleh perbankan sebagai sumber dana. Dengan mengembangkan kemampuan menabung mereka, ketahanan masyarakat dalam menghadapi kebutuhan-kebutuhan yang bersifat mendesak seperti sakit, musibah maupun kebutuhan mendesak lainnya menjadi semakin kuat.

Pada tahun 2010, telah ada sekitar 4.000 BMT yang beroperasi di Indonesia. Beberapa diantaranya memiliki kantor pelayanan lebih dari satu. Wilayah operasionalnya pun sudah mencakup daerah perdesaan dan daerah perkotaan, di pulau Jawa dan luar Jawa.

BMT tersebut diperkirakan melayani sekitar 3 juta orang nasabah, yang sebagian besar bergerak di bidang usaha mikro dan usaha kecil. Cakupan bidang usaha dan profesi dari mereka yang dilayani sangat luas. Mulai dari pedagang sayur, penarik becak, pedagang asongan, pedagang kelontongan, penjahit rumahan, pengrajin kecil, tukang batu, petani, peternak, sampai dengan kontraktor dan usaha jasa yang relatif moderen.

Perkembangan BMT yang pesat diiringi pula oleh semakin besarnya tantangan yang dihadapi. 
Tantangan internal terpenting diantaranya adalah: soal kepatuhan syariah (syariah compliance), soal mempertahankan idealisme gerakan, soal profesionalisme pengelolaan, soal pengembangan sumber daya insani, dan soal kerjasama antar BMT. Sementara itu, tantangan eksternal yang utama adalah: dinamika makro ekonomi, masalah kemiskinan yang masih menghantui perekonomian Indonesia, dinamika sektor keuangan yang belum menempatkan keuangan mikro sebagai pilar utama, serta masalah legalitas dan regulasi untuk BMT.

\section{KESIMPULAN}

Lembaga sektor keuangan sangat dibutuhkan dalam mendukung permodalan dalam sektor riil, hal ini sudah dirasakan fungsinya sejak beberapa puluh tahun yang lalu di Indonesia dengan konsep perbankan, baik yang berbentuk konvensional (berdasarkan kapitalis maupun sosialis) dan berprinsip syariah. Akan tetapi perbankan itu sendiri belum menyentuh terhadap usaha mikro dan kecil (UMK) baik dari pedagang kaki lima sampai pedagang-pedagang yang berada di pasar tradisional yang biasanya disebut sebagai ekonomi rakyat kecil.

Didorong oleh rasa keprihatinan yang mendalam terhadap banyaknya masyarakat miskin (yang notabenenya umat Islam) yang terjerat oleh rentenir dan juga dalam rangka memberikan alternatif bagi mereka yang ingin mengembangkan usahanya namun tidak dapat berhubungan secara langsung dengan perbankan Islam (baik BMI maupun BPRS) dikarenakan usahanya tergolong kecil dan mikro, maka pada tahun 1992 lahirlah sebuah lembaga keuangan kecil yang beroperasi dan menggunakan gabungan antara konsep Baitul Maal dan Baitul Tamwil yang target, sasaran, dan skalanya pada sektor usaha mikro. Lembaga tersebut kemudian diberi ama Baitul Maal Wat Tamwil yang disingkat BMT.

BMT ini lebih dikelola oleh beberapa individu dan menjangkau sektor mikro dari perekonomian rakyat, selain mempunyai dana untuk kegiatan konsumtif juga pendanaan untuk kebutuhan produktif bagi usaha mikro dan kecil (UMK) yang tentunya sesuai dengan prinsip yang ditentukan oleh Islam atau sering disebut dalam tulisan ini sebagai prinsip syariah.

\section{DAFTAR PUSTAKA}

Adiwarman, 2004 Bank Islam, Analisis Fikih dan Keuangan, Raja Grafindo Persada Jakarta

Amin Aziz 2006 Buku Tata Cara Pendirian Baitul Maal Wa Tamwil (BMT) dan Kisah Sukses BMT , PKES, Jakarta

Antonio Syafei, 2001, Bank Syariah dari Teori ke Praktek, Gema Insani Press Jakarta

Baitul Maal, Gerakan Ekonomi Umat, Sabili, No.21/Th IV, 1-4 Juli 1992

Hafiduddin Didin, 2002, Zakat dalam Perekonomian Modern, Gema Insani Press Jakarta 
Heri Sudarsono. 2007 (cetakan keempat). "Bank dan Lembaga Keuangan Syariah "Deskripsi dan Ilustrasi" Ekonosia Yogyakarta

Karin Adiwarman, 2004 Bank Islam, Analisis Fikih dan Keuangan, Raja Grafindo Persada Jakarta

Karnaen A. Perwataatmadja, Drs, MPA ( I 996), Alternatif Pemecahan Masalah Ekonomi Umat dan Kemungkinan Mengembangkannya (Makalah),
Mahmoud al Ansori, Ismail Hasan, Samir Mutawali, Perbankan Islam,

Sejarah, Prinsip dan Opersaional, 1993.

Praktek bank Tanpa Bunga, Sabili, No.6/Th 14 Rabi'ul Akhir 1412 $\mathrm{H}$.

Yusuf Qordhowi, Bank Tanpa Bunga, Usamah Press, Jakarta, 1991. 